\title{
Creativity in Architecture as a Precursor of an Evolving Cultural Development - Case Study: Ars Aevi, Museum of Contemporary Art, Sarajevo, Bosnia and Herzegovina
}

\author{
By Nina Ugljen-Ademovic ${ }^{*}$ \\ Senka Ibrisimbegovic ${ }^{\dagger}$
}

\begin{abstract}
Contemporary theoretical concepts in architecture are almost unimaginable without new perceptions of the importance of cultural identity. Today, this very sensitive question deserves careful attention, especially in small countries, in which transitional processes are still present. Importance of the architecture in this process is invaluable. Architecture visualizes values of a culture by its formal sensations. That characteristic guides us to perceive development and upgrade the cultural identity from two positions - through both the implications of place and time. In specific complexity the cultural identity of Bosnia and Herzegovina was created out of sources susceptible to the various influences as well as reshaped, embodying social awareness. In this context, an analytical model is constructed for the purpose of finding answers to burning questions - in which way architecture and urban forms influence the shaping of the cultural identities of societies in transition and how this cultural identity becomes locally and globally sustainable.
\end{abstract}

\section{Introduction}

Throughout history architecture is linked to the question of development of cultural identity, its meaning and perspectives, and ways of its extension in a contemporary context.

Anthropologists and theorists of culture, have difficulties in taking a common position on what culture is by definition. This is somehow not acceptable, if we want to understand culture as a complete pattern of human behaviour and if we interpret it in accordance with the actual needs of society as a "context for communication". 1

In order to indicate the need for constant upgrading of cultural identity and stress the importance of creative attitude towards it, we shall use Pierre Bourdieu's concept of "habitus". By translating it to the field of architecture, we will show how the architecture really implies cultural values embedded in the works that have cultural meaning and are layered for promotion, and become an important driver of development of society as a whole.

\footnotetext{
${ }^{*}$ Professor, University of Sarajevo, Bosnia and Herzegovina.

${ }^{\dagger}$ Senior Teaching Assistant, University of Sarajevo, Bosnia and Herzegovina. 1. www.nasponline.org. 2015.
} 
"Habitus is especially developed through processes of socialization and determines a wide range of dispositions that shape individuals in a given society. It is not a 'structure' but a durable set of dispositions that are formed, stored, recorded and exerts influence to mould forms of human behavior. It may vary in accordance to the social environment, because unstable social domains may produce unstable systems of dispositions that generate irregular patterns of action. It reinforces cohesion but also stimulates change and innovation, especially when it does not fit the surrounding social world where it evolves. ",

Coming out of the realm of pure appearance, as reality suggests to us, and relying on the individual effect within a complex social structure, our research will characterize the duality of views. One point of view will continue to be directed towards, already mentioned, clean appearance in which architecture is involved through its form, while the other will emphasize its metaphysical property. This metaphysical is the one with which architecture on immaterial, but a very definite way, affects the life of every human being and at the same time develops processes of identification of the man with the space that surrounds him, by systematically changing it.

The importance of such attitude is perhaps best illustrated in Lefebvre's dialectical concept of creating a space in which action, understanding and settlement equally constitutes a "third space", ${ }^{3}$ open space of social reality. Relationships that take place within it, enrich it, and its value "lies dormant and in permanent potential, but it has to be reactivated by social practices." ${ }^{4} \mathrm{By}$ recognizing different forms of culture that constitute cultural identity, it becomes clear that architecture has a special importance not only because of its durability and ubiquity, but also due to the fact that it conceptually determines the spatial dimension of identity. In that sense, architecture affects the construction of the intangible, revived in the concept of genius loci.

Therefore, before taking a certain attitude it is necessary to find answers to some important questions, such as - "how to evaluate and determine the identity of a given area, the importance of cultural memory in the modern concept of cultural identity, and, in that way the author's creative potential of contributing to the formation of spatial identity?"

\section{Cultural Identity - Constant or Variable Dynamic Process}

Consideration of the spatial dimension of identity is crucial in understanding the unique role that architecture creates. To understand the certain spatial concept and its importance as the largest and most important

2. Zander Navarro, In Search of a Cultural Interpretation of Power: The Contribution of Pierre Bourdieu (IDS Bulletin, 2006), 6.

3. Henri Lefebvre, The Production of Space (Oxford Blackwell Publishing, 1991).

4. Neil Leach, "Belonging: Towards a Theory of Identification with Place," Prospecta 33 (2002): 126-133 
resource is extremely important because, above all, it embodies our relationship with the place.

The architect intuitively searches for an analogy with the social phenomena that surround it, and from this continuous process an architecture that visualizes the value of the culture throughout its formal sensations rises.

This way of defining the problem alludes to the development of cultural and spatial identity as an interdependent in the process of changing and upgrading. Only their juxtaposition can offer vitality to a certain area.

However, the problem arises when we are unable to allow spontaneous implications of cultural identity in the architecture and vice versa, that is, when we deduct identity from its vital values, turning it into a tool entirely noncompatible to the values it entails. At the point where dynamic, evaluative and natural process is denied due to the impossibility of observation and evaluation of the true value. The result may be of very harm - from insisting on a static, ideological, closed conception of the space subordinated only to a particular cultural milieu, to the ignorance of the continuity of supporting ephemeral tendencies in architecture, which are pushing "new age" theory and promoting the company of "spectacle", leading to the formation of "non -place" (Marc Auge non-places) closed and self-sufficient.

Such "hypertrophied" ideas lead to the loss of identity and prevent an important idea of the place as a phenomenon that, as stated by Daniel Liebeskind "needs to resist the erasure of history, needs to respond to history, and needs to open the future." Each of these approaches undermines, in their own way, the process of upgrading cultural identity; while at the same time breaks down the space, making it a non-compliant set of isolated sequences. Then, it becomes a place with no coherence, and creative diversity, and loses its own identity, spatial identity.

The complex situation in recent decades increases the need for a proper evaluation of the urban areas due to the divergent ways of intervention in the space, as well as due to the impact of globalization processes in all spheres of life and, finally due to ever-changing concepts of modernization in the greatest possible way.

This is one of the reasons why the importance of the place deserves recognition as one of those phenomena that make up the blend of cultural and social experiences and features of our affiliation, ceases to be not only spatial, material built structure, but also to what is not built, going out of its borders.

We suggest replacing the Heideggerian ontology of being-in-theworld with a more Deleuzian notion of becoming-in-the world. This implies a break with static, fixed, closed and dangerously essentialist notions of place, but preserves a provisional ontology of place-asbecoming: there is always, already and only becoming-in-the-world. I also suggest we replace the division of subjectivity-objectivity or

5. Daniel Liebeskind, "Traces of the unborn." in Architecture and Revolution: Contemporary Perspectives on Central and Eastern Europe, ed. Neil Leach (London: Routledge, 2003), 127. 


\section{people-environment with Bourdieu's concept of the habitus as an embodied world. ${ }^{6}$}

Pointing to the permanent link between architecture and society, understanding the contemporary context suggests a combination of spaciousness and social awareness, at the same time not depriving the architecture from its democratic right to be a reflection of its time. In this context we accept global culture as a paradigm of actual time and technological achievements, which resists to omnipresent commodification only through thoughtful, culturally conscious architecture. Finally, we paraphrase the words of Roland Robertson, for whom globalization is not a one-sided process, but it is also a way of highlighting the new locality. ${ }^{7}$

Starting from the fact that cultural identity constructs, upgrades, and thus changes in response to various influences in the environment, we believe that in this specific genesis, which is implied by the architecture, there is a need to search for an embodiment of Auge's "anthropological place", filled with history, identity and interaction. ${ }^{8}$

\section{The Implications of the Memory of the Place}

Thus it becomes clear that, speaking of the space that surrounds us, and which is embodied by the architecture, we talk about the substantive notion of our existence. Contemporary awareness of space is created at the turning point of its territorial and memorial meaning. Seeking to reassert the importance of the "anthropological place" we are aware that the concept of memory is present and is being developed at different levels. It is an inalienable right of every man filled with a number of subjective associations.

If we imply a term of memory in a contemporary issue of designing space, we are obliged to do it very carefully, being aware of the fact that social

6. Kim Dovey, Becoming Places Urbanism/Architecture/Identity/Power (New York: Routledge London, 2010), 6.

7. John Tomlinson, Globalization and Culture (Nottingham: The University of Chicago Press, 1999), 30. View of Roland Robertson, who argues that in globalization the world becomes a single place that serves as a frame of reference to everyone. What unites Giddens and Robertson is the idea that globalization is a reflexive process. In a sense, participants must monitor the impact of changes on their lives and must identify their own position in relation to the larger process. No one can feel comfortable "at home" anymore. But globalization has a bright side: as it "dissolves the securities of locality, it offers new understandings of experience in wider-ultimately global-terms".

8. Marc Augé, Non-places. Introduction to an anthropology of super modernity (London/New York: Verso, 1995), 77. Augé uses a notion of place, which already contains the sense of "anthropological place" with language and movement in it. Place, he asserts, "can be defined as relational, historical and concerned with identity". Ibid, 79. Accordingly, the specificity of a place makes it a reference point and source of identification for citizens living in the vicinity. Augé's concept of place is clearly charged with emotion and memory. Opposed to a place, according to Augé, is the concept of a non-place. Ibid, 77-78. This is described as a "space which cannot be defined as relational, or historical, or concerned with identity" and is thus devoid of emotion and memory. 
interaction in the area includes historical and temporal dimension, spiritual and material, individual and collective.

We are also aware that the specific sensibilities of a certain area and a certain place can be truly experienced only through "direct and genuine experience of the entire complex of the identity of places - not mediated, and distorted through a series of quite arbitrary social and intellectual fashions about how that experience should be, nor follow stereotyped conventions."

However, nowadays the cultural memory is increasingly being replaced by the communicative memory, which means that our memories are becoming shorter, and Norberg-Schulz resources/tools of building space, symbols and metaphors, are almost a thing of the past.

"Our memory, which we possess as beings equipped with a human mind, exist only in constant interaction not only with other human memories but also with "things", outward symbols."10

\section{The Cultural Development Process}

Can we reach the authenticity of a given place to reflect the cultural identity that has to be open and ready to upgrade, and can we preserve the memory of the place, and at the same time respect the zeitgeist? Our further consideration will be based on reflections of Jan Assmann, in which cultural memory has an important capacity for renewal.

"No memory can preserve the past. What remains is only that "which society in each era can reconstruct within its contemporary frame of reference". Cultural memory works by reconstructing, that is, it always relates its knowledge to an actual and contemporary situation. True, it is fixed in immovable figures of memory and stores of knowledge, but every contemporary context relates to these differently, sometimes by appropriation, sometimes by criticism, sometimes by preservation or by transformation." 11

Inability to understand this statement, and draw lessons from it, has farreaching consequences on the implications of cultural identity in architecture and cultural development as a whole. We have to look for the answers in the idea that today's urban spaces are ambivalent by their visual expression and it may be difficult to match certain cultural patterns. Therefore, we are witnessing the redefinition of the concept and meaning of spatial identity, which not only keeps on changing its external characteristics but also touches on the essence of what it is by disturbing the content itself. Cities, once gathering places and spatial integrations, are losing their identity and are unable to generate a new architecture.

9. Edward Relph, Place and Placelessness (London Pion, 1976), 64.

10. Jan Assmann, Cultural Memory Studies. An International and Interdisciplinary Handbook (Berlin, New York: 2008), 3.

11. Jan Assmann, "Collective Memory and Cultural IdentityFrankfurt/Main," in Kultur und Gedachtnis, ed. Jan Assmann and Tonio Holscher (Suhrkamp, 1988), 6. 


\section{Cultural Development in Bosnia and Herzegovina}

Bosnia and Herzegovina is also facing a process of transition, in a very specific and difficult way. In this process, culture suffers the most, about what we will elaborate further using Sarajevo, the capital of Bosnia and Herzegovina, as a representative example. We perceive cultural identity of Bosnia and Herzegovina through a reflection on its historical and geographical position. The country is positioned between civilizations of the Occident and the Orient and the cultures of the continental Europe and the Mediterranean. It has been influenced by fast and frequent changes of socio-political systems (Figure 1).

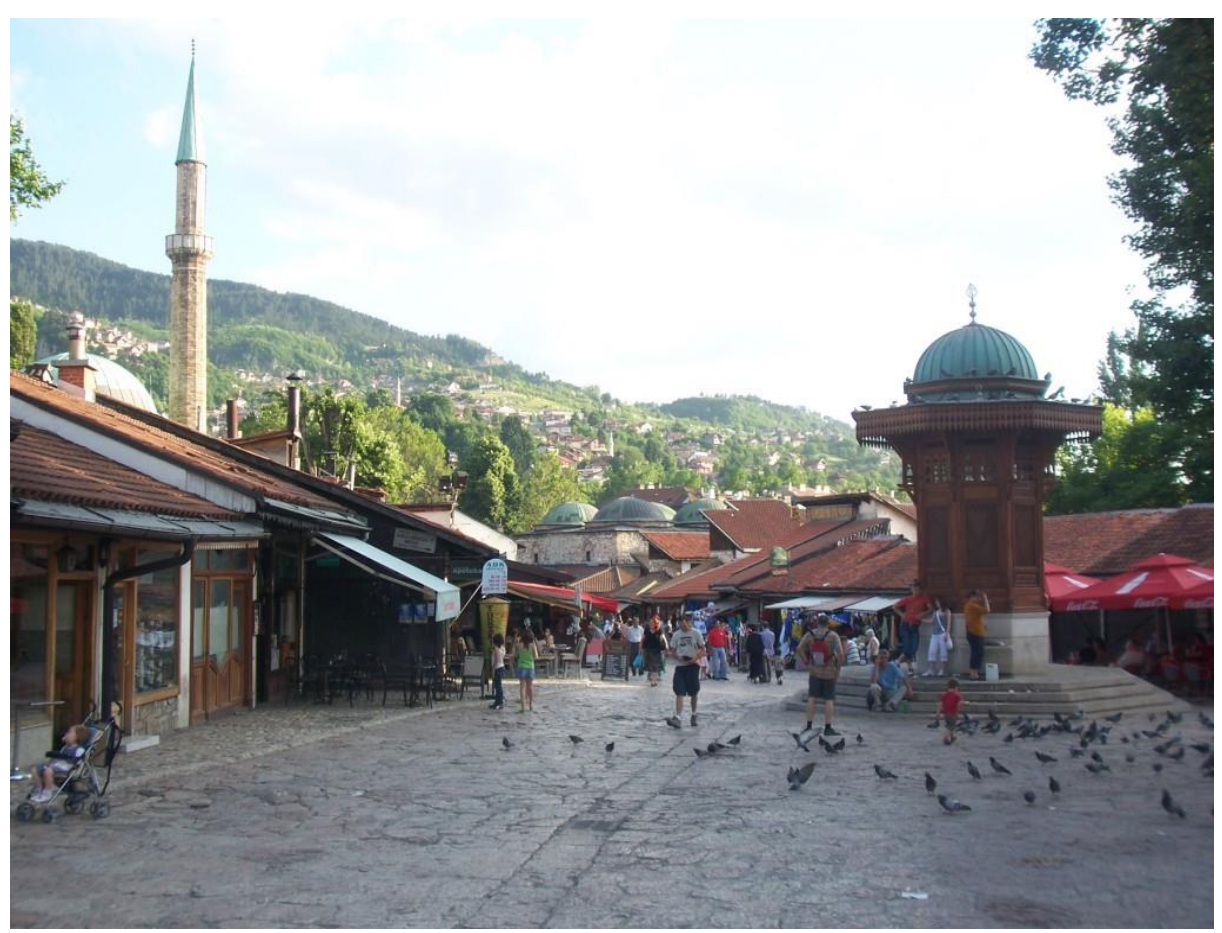

Figure 1. Sarajevo Old City from Ottoman Period, Bascarsija

In a specific complexity of its position, always peripheral, compared to large cultural and political centres, the formed cultural identity of Bosnia and Herzegovina has been opening to different influences reshaping and incorporating its social awareness. In the uniqueness of such a cultural context quality architecture emerged, and its "modern legacy" created an intriguing area for research and valorisation (Figure 2). 


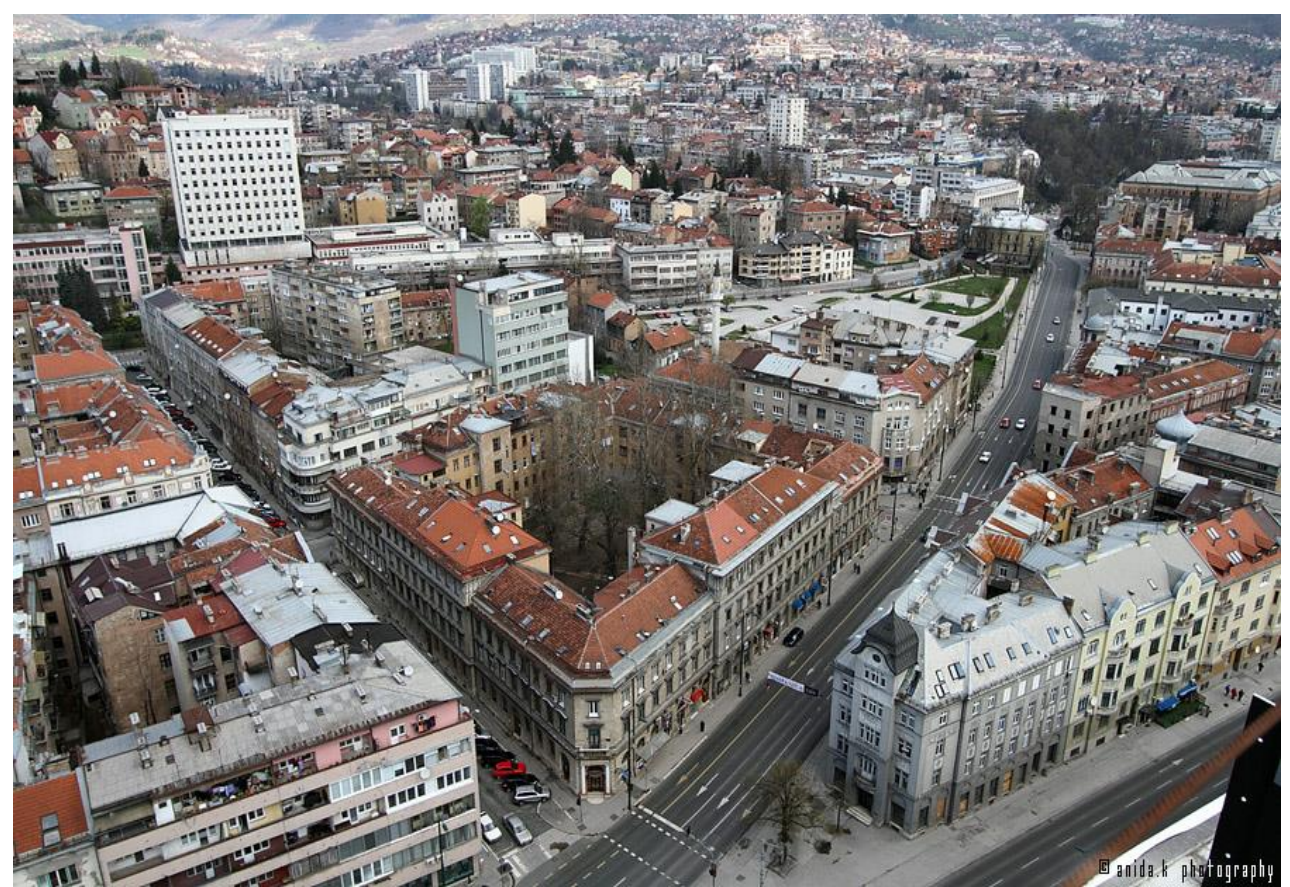

Figure 2. Sarajevo City from Austro-Hungarian Period, Marijn dvor

Source: Author: Anida Krećo Photography.

Our starting point is that variable processes of modernization, followed by architecture since the beginning of 1990, which represent an undivided part of our cultural legacy, rich in positive experiences, are unfairly neglected today. This is the reason why cultural identity forming process is losing the abovementioned characteristics and becomes the tool of other certain planned interests.

The duality of returning to national-oriented society and unselective dictatorship of the capital almost excludes the values achieved by the architectural modernization processes. In this manner, post-socialist modern society tends to erase valuable historical architectural examples, but the consequences are far more complex - the links in the continuity of our cultural identity may disappear. This process resulted with the current situation, which is in a constant race between retrograde attempt to return to the nationally oriented architecture, the establishment of a homogeneous cultural identity and architecture that wants to create a new identity relying on non-selective dictation market. These attempts clearly threaten the continuity of the development of cultural and spatial identity, what are, in the first place, threatened valuable examples of modern cultural heritage (1945 - 1992).

This study has the aim to try to provide answers for the questions raised in the Introduction, but represent a peculiar appeal for awakening the conscience on the significance of architecture of our past, on a local level and further. 
Redefining the attitudes towards this kind of architectural legacy will gradually lead to redefining the term of the cultural identity what will be presented in the other part of this study. ${ }^{12}$

Heterogeneous areas caused by complex and changing socio-political influences require an analytical approach to the creative renewal that paves the way to the Ulrich Beck's concept of "transcultural", open and diverse. ${ }^{13}$ This is the way to proper evaluation and regeneration of cites and facilities that have been and can again be a creative symbiosis of architectural, symbolic, metaphorical and historical value. ${ }^{14}$

In the case of Bosnia and Herzegovina, one of the most valuable among them is the Historical Museum in Sarajevo, former Museum of the Revolution, which will serve as an example of authorial creativity that builds cultural identity and its sensitivity to the environment. Museums humanize the environment and socialize architectural work. They also tend to be generators for cultural, economic, urban, educational and social development in a town and in a region, so the continuity of creating this kind of architectural buildings is important in having continuity of creating a cultural identity.

\section{Case Study}

Historical Museum in Sarajevo as Existing Architectural Value

Architectural design of the Historical Museum, designed by the Croatian architects (B. Magaš, E. Šmidihen and S. Horvat) in the 1960's, in the beginning of their creative careers, was based on a disciplined adoption of modernist practices not only in the field of architecture, but also from the culture in general (Figure 3).

12. Nina Ugljen-Ademović, Elša Turkušić and Senka Ibrišimbegović, "The Process of redefining Cultural Identity in Societies in Transition- case study: Historical Museum in Bosnia and Herzegovina," proceedings of 2nd international conference, Architecture and Civil Engineering (Singapore: ACE, 2014), 366.

13. Urlich Beck, Šta je globalizacija? [What is globalization?] (Zagreb: Vizura, 2001).

14. Many social theorists have suggested that we are currently living in a period in which the identities of the past are becoming increasingly irrelevant and in which new identities, and new identity formations, are being created. The major identity colossus forged in the nineteenth century, and subsequently spread over much of the globe - nation state identity - has been the subject of particular debate; and theorists have attempted to identify alternative, post national (in the sense of post-nation-statist) identity constructions. (Macdonald n.d. http://bit.ly/1RK sxX9). 


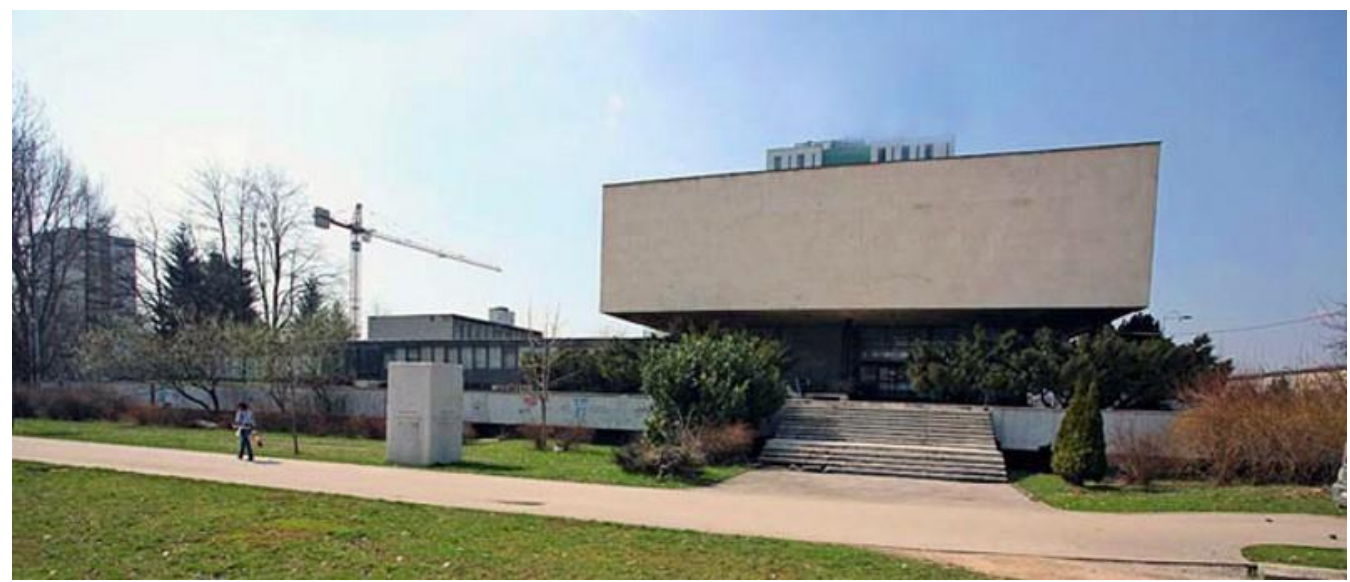

Figure 3. External East View of Historical Museum, Sarajevo

Source: Historical Museum Photo Archive.

The architectural heritage of modernism in Bosnia and Herzegovina is valuable in many different ways. It shows a strong mark of the tendencies of its era, but also of signature styles of renowned regional, European and even world-known architects. Mostly, these are buildings whose visual identity is often even ahead of its time. Leaning on the urban and architectural experience of the last periods (the Ottoman and Austro-Hungarian architecture), architectural modernism, although autonomous and functions beyond spatial and temporal realities, is the true bearer of cultural memory and the constructive creator of Bosnian national and cultural identity.

Without insisting on the interior design, as Magaš said, the architects made a memorial, one sign of the times, and "if we're lucky, it will remain a monument to a time and to the people to whom it is dedicated." The author believes that if we create an architecture that does not match either our time or function, or the characterization of the construction site, it then gets out of the domain of truth. It takes an effort to realize the characterization of space, form and given time, which tells the truth of human creative works by using the clearest language build, transcending into a formative component. ${ }^{15}$

The Historical Museum of Bosnia and Herzegovina today obviously exists in very poor physical condition, which is a result of the lack of political decisiveness regarding the maintenance of the heritage of modernist architecture. However, the management of the institution is trying to use spatial resources for a variety of cultural activities (exhibitions, educational workshops for children and adults, bazaars, scientific research panel discussions and lectures), which confirms that the area is able to house activities that are complementary to its original purpose - affirmation of the progressive tendencies that are contained in the program of the museum but also in its architecture (Figures 4, 5).

In order not to leave this pearl of Modernism in Sarajevo to luck, it is necessary to acknowledge the needs of policy management and maintenance of the heritage of modernist architecture and ways of their continuous and rational

15. Fra Marki Ešegović, Svjetlo riječi [Light of the word] (Sarajevo, 2011). 
adjustment to current needs. In this way, it will also gain a possibility to show its potential and role in the formation of contemporary local cultural identity. Because, as Mrduljaš says, "deleting the tradition of modern architecture and the ideas behind them will mean giving up the active and genuine contribution to the global culture and leaving a provincial and completely marginalized situation where local or universal mean nothing."16

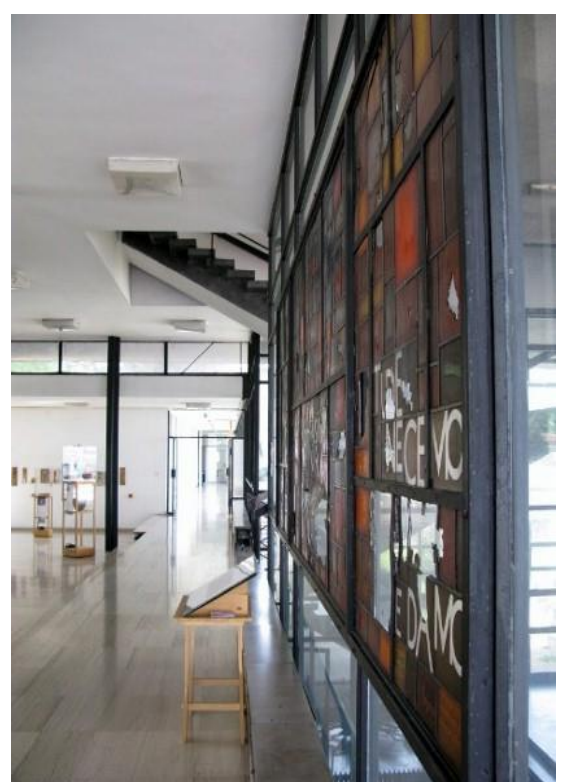

Figure 4. Historical Museum, View of Exterior Garden near Entrance Source: Historical Museum Photo Archive.

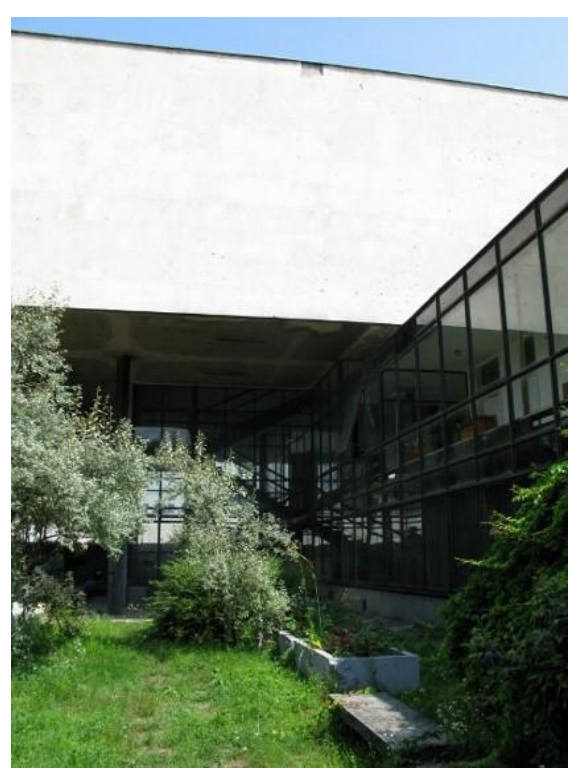

Figure 5. Historical Museum, View from Courtyard towards the Street Source: Historical Museum Photo Archive.

16. M. Mrduljaš and V. Kulić, "Unfinished modernisation," Cres/Fort Lauderale May (2012). 
Therefore, this homage to the "modern heritage" should be properly evaluated, and its potential in the formal and functional terms maximally exploited. If we remember that the architecture is a testimony on creativity of humans in the field of construction and every moment that leads to its manifestation must be true.

Ars Aevi, Museum of Contemporary Art as a Precursor of an Evolving Cultural Development

The Ars Aevi collection began with the establishment, during the war, (1992-1995) as an expression of the international collective will of world artists and international contemporary art museums. In a specific way, this gesture was an appeal for peace in Bosnia and Herzegovina. Such Collection was brought to Sarajevo in 1999 after the war ended.

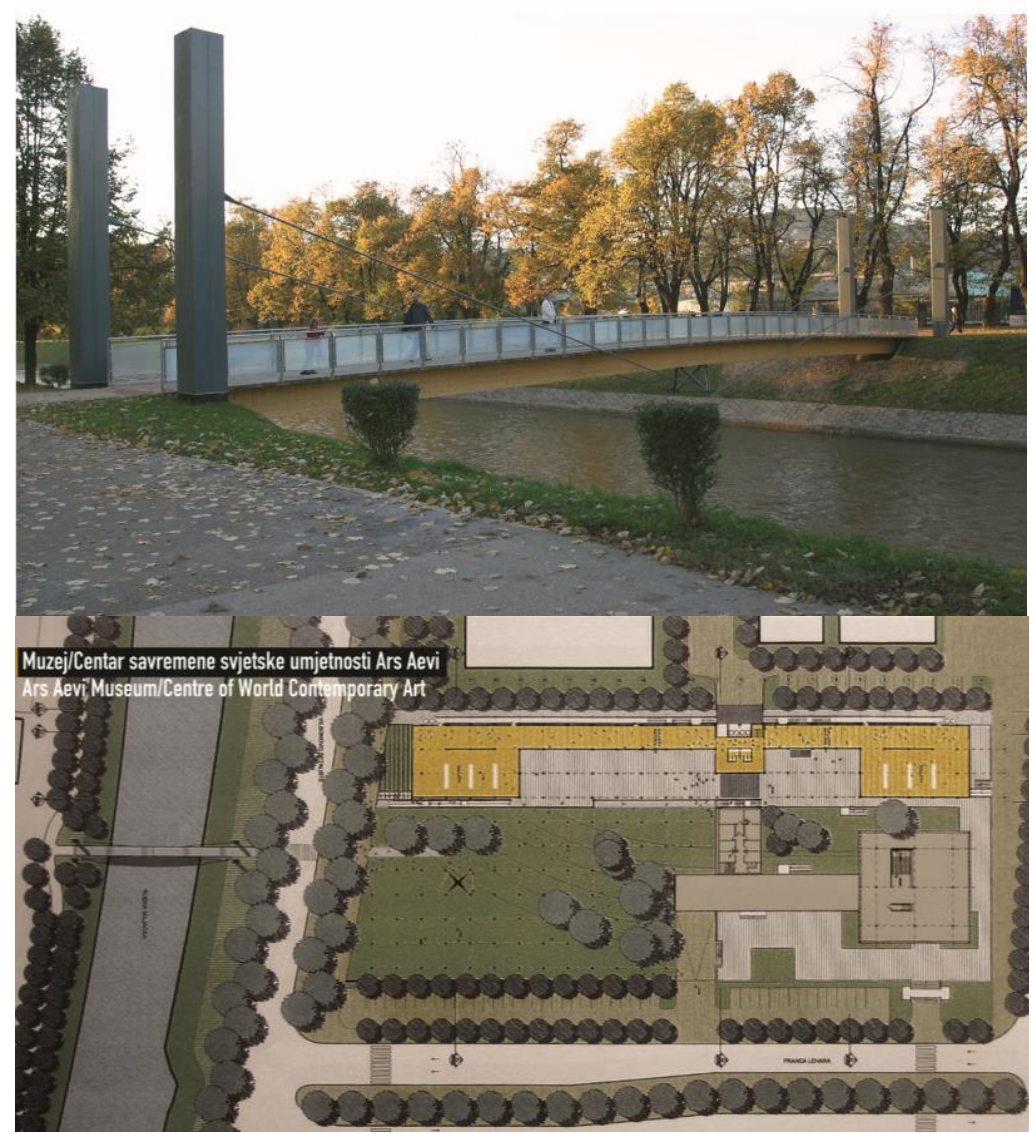

Figures 6, 7. Built Footbridge ARS AEVI; The Situation of the Future Ars Aevi Museum and the Pedestrian Bridge

Source: Ars Aevi Museum Photo Archive.

Preliminary architectural design of the future Museum of Contemporary Art, Ars Aevi, signed by one of the world's most known architects, Renzo Piano (as Goodwill Ambassador of UNESCO), was officially promoted in Sarajevo in September 2006. Under this project, the building should be built on 
the site of Quadrant C on Wilson Boulevard, with the support of the Municipality of Novo Sarajevo. Location Ars Aevi Museum covers an area of $5453 \mathrm{sqm}$. The object of the museum, according to the project, will cover an area of $2650 \mathrm{sqm}$. The total projected area is $4875 \mathrm{sqm}$, divided into three floors (Figures 6, 7).

The idea of architect Renzo Piano is to form a building as a dynamic urban centre where art is not perceived as "closed" and "unavailable" but, through a combination of galleries, social and commercial space it should be available and open to multiple stakeholders.

Part of the building, therefore, makes the high frequency pedestrian zone, which links the adjoining residential area of Grbavica with the main road and the future University Centre. For this reason the building was specifically aimed at the Grbavica neighbourhood, whose residents in the future museum introduce the pedestrian bridge, which was designed by the architect and the construction of which was financed along with his Italian partners in 2002. The project is articulated around the Historical Museum as a longitudinal structure that follows the footpath, which introduces the contents on the ground floor, situated in segments of the interior walls which are transparent to the outside, providing visual communication between the outer and inner space. From the ground floor the way in the basement garages, which is partially underground, but has natural light, is designed (Figures 8,9).
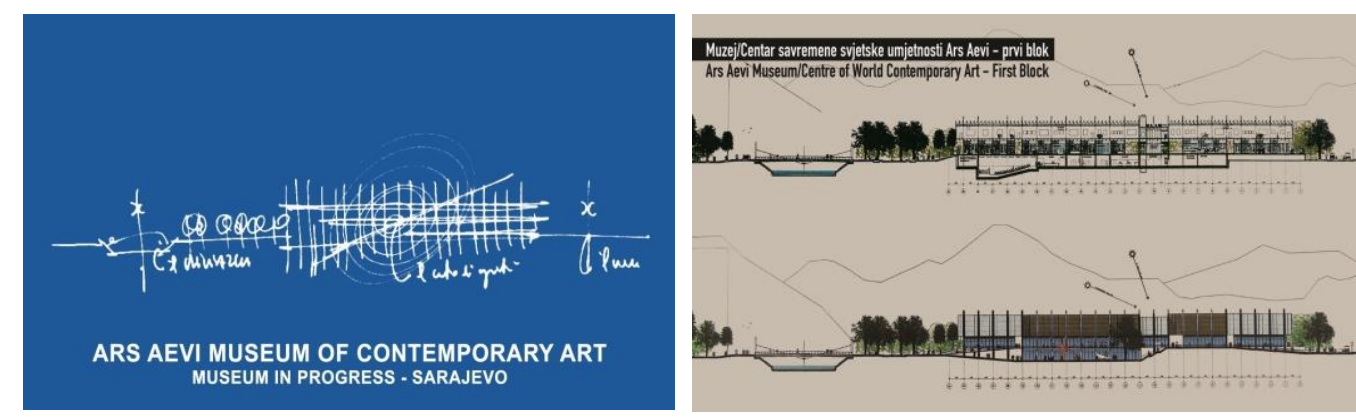

Figure 8, 9. Sketch of the Ars Aevi Museum, Architect Renzo Piano. The Preliminary Sections of the Future Ars Aevi Museum

Source: Ars Aevi Museum Photo Archive.

Sarajevo does not have a museum of contemporary art, because the city politicians mean that there are bigger problems and bigger responsibilities to be solved. Ars Aevi collection is now located in the Skenderija city centre, is open to the public and mainly promotes contemporary art outside of Bosnia and Herzegovina. In 2009 Ars Aevi presented, along with architectural design, in the presence of Renzo Piano, contemporary artist Braco Dimitrijevic at the $53^{\text {rd }}$ Venice Biennale (Figures 10, 11). 


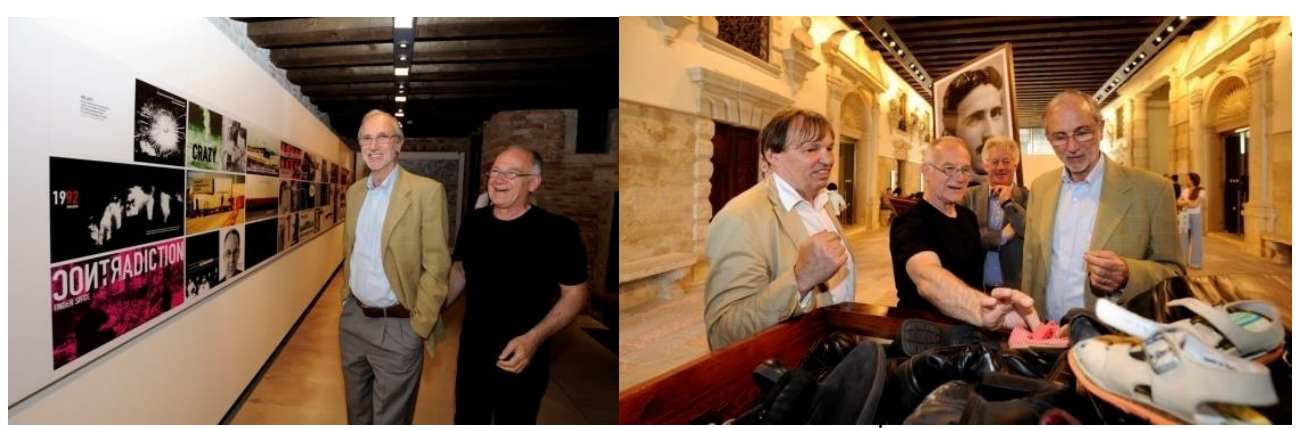

Figures 10, 11. Architect Renzo Piano at the $53^{\text {rd }}$ Venice Biennale with Ars Aevi Director Enver Hadziomerspahic; Artist Braco Dimitrijević, Enver Hadzimerspahic, Renzo Piano in la Ca'Pesero at Dimitrijević's Exhibition Source: Ars Aevi Museum Photo Archive.

"This situation can be viewed from many angles. Of course, the first is the perspective of those who run this society. So, they do not realize the richness of the Ars Aevi collection and it can present us all, and I mean the whole country, in a wider context of Europe or the world and, of course, the political establishment as an essential project does not recognize it. I think that's one unique idea and concept of the museum, which is at the world level and thus gaining this area in an urban setting, it can enrich and contribute to the development of the urban space. It is not easy to find the optimal model for realization of this project. Today, the mixed, public and private sector, model can be used for the realization of certain cultural projects, which are for the benefit of the whole society. The challenge is to bring this idea to the public, in order that the museum becomes the public good of all citizens of Sarajevo and Bosnia and Herzegovina. This is a capital idea to world standards and thus the importance of the project is clear." Adnan Harambašić a Bosnian/Norwegian architect, said in an interview. ${ }^{17}$

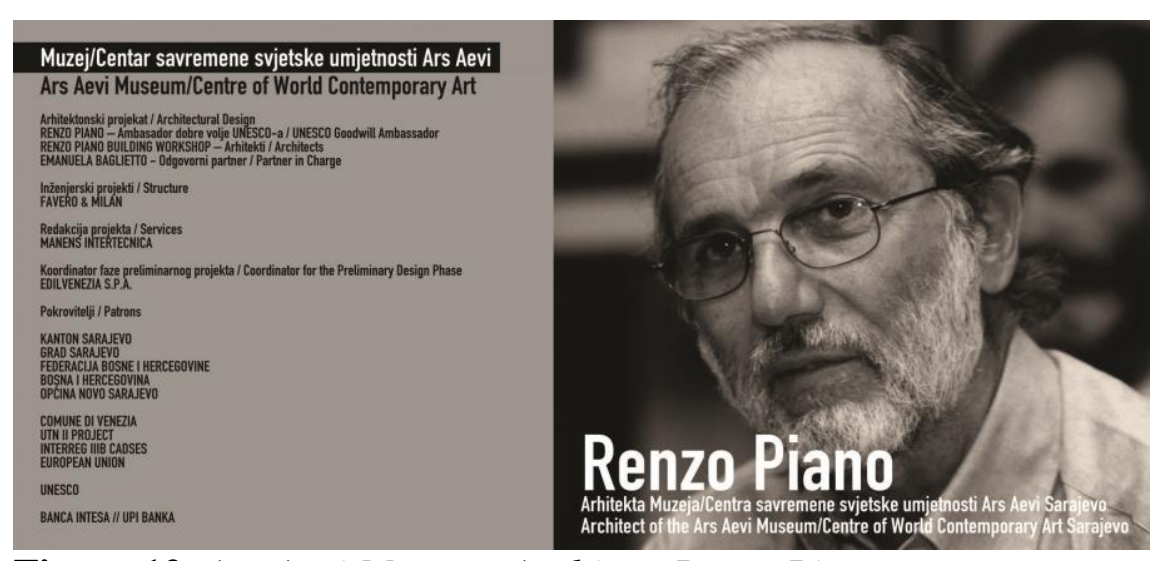

Figure 12. Ars Aevi Museum Architect Renzo Piano Source: Ars Aevi Museum Photo Archive.

17. Senka Ibrišimbegović, Arhitektura muzeja savremene umjetnosti kao kapsula vremena [Architecture of museum of contemporary art as time capsule] (Sarajevo: $\mathrm{PhD}$ Dissertation, 2015), 184 
Designing a museum of contemporary art in Sarajevo (collection of Ars Aevi) by architect Renzo Piano is a global exchange value (Figure 12). Beyond the architecture of the future museum, which is likely to be a range of world architecture, there is a lot more complex social mechanism, by which the society can become a brand, city, culture, developing tourism, etc. ${ }^{18}$

Such a case occurred eg. with the project and construction of the Guggenheim Museum in Bilbao, in the 90's of the $20^{\text {th }}$ century, with interesting social effects, one of which is an annual visit to the museum by million tourists. The construction of the museum in Sarajevo would surely have positive results, in educating the population, urban development and economic growth. The students and young scholars were surveyed for the needs of this museum, because they are considered the generation that is the future of this country. They can and should have an awareness of the need for cultural institutions in a society, in this case the museum. Such synergy results by creating inspirational space for the whole society, for the development and advancement of creative and conscious abilities in children of preschool age. And that is the basis for a healthy and creative society.

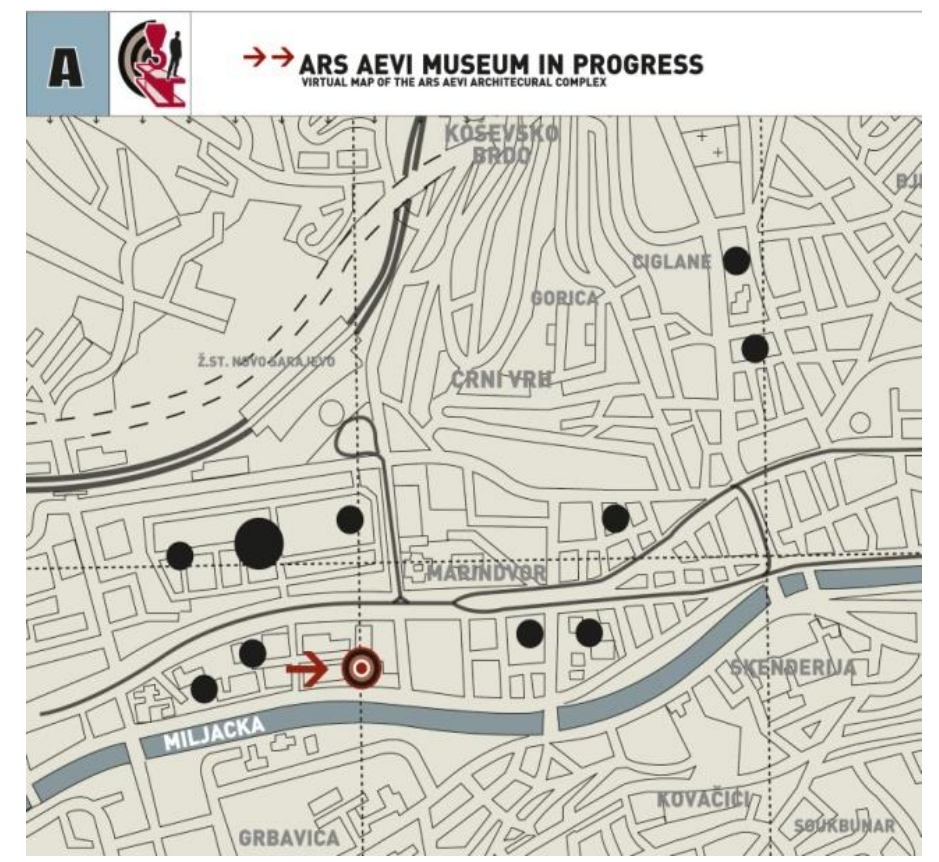

Figure 13. The Preliminary Sections of the Future Ars Aevi Museum; Sketch of the Ars Aevi Museum, Architect Renzo Piano

Source: Ars Aevi Museum Photo Archive.

It is believed that the construction of the Museum of Contemporary Art Ars Aevi would have a positive impact, not only on the construction area and "Museum quarter" as part of the planned facility, but also for the city of Sarajevo, and the entire Canton Sarajevo and B\&H. Due to the constant

18. Fehim Hadžimuhamedović, Katedrale novog duha; Društveni red arhitekture [Cathedrals of new spirit; social order of architecture] (VIZURA, 2007), 12. 
expansion of the Ars Aevi collection, there are proposed strategies for the expansion of the Ars Aevi facilities throughout the city, which would be small museums of modern art, which is the trend of the future tendencies of architecture museum of contemporary art world architects and museum professionals. We hope that conditions for the construction of the Museum of Contemporary Art Ars Aevi will be created soon (Figure 13).

As Maroevic says, " ... it is the future of contemporary museums, and in that sense any future museum architecture should be seen in the context of the opening of the environment, tear of barriers, leaving of the monumentality, eliminating unnecessary awe and solemn mood and achieving something that has dignity, but reserves special and everyday life relationship with the environment and people.",19

\section{Conclusions}

It can be concluded that architecture is perceived as a powerful medium through which an individual or a community determines its place in history, conveying ideas and setting criteria. The importance of the architecture in the process of creating the cultural identity is invaluable. Architecture visualizes values of a culture by its formal sensations. Hence, it is important to understand architecture as an influential tool capable of transferring ideas and setting the criteria for determination of the place, either of individuals or communities. That characteristic guides us to perceive development and upgrade the cultural identity from two positions - through both the implications of place and time. We can confirm that the meaning and identity of the area is based on the fundamental human need to give meaning to its existence. Such architecture is a synthesis of spatial creation wherever it occurs, leading to the physical identity, a place where old and new diverges together to form a new value (genius loci).

"Since ancient times man has noticed that different places have a variety of characteristics. These characteristics can be so pronounced that in fact they determine all the basic forms of our environment, thus contributing to most of the people who live there to feel that they belong to the same place. There were such cases, when the genius loci proved so powerful that it was able to dominate the political, social and cultural changes.

Cultural identity of specific regions has implications on its architecture. In this way it represents an inevitable and continuous process of the permanent labelling of the place in the terms of the symbolic identification with the territorial and memorial significance.

19. Ivo Maroević, ČOVJEK I PROSTOR Novija muzejska arhitektura u Hrvatskoj [Recent museum architecture in Croatia], 9. 
The problem persists when present contexts are not able to generate new architecture. The creation of such socially responsible architecture would contribute to necessary redefining the architectural processes if we aim to build buildings, which would on the one hand respect the past, but also on the other hand open new visions of the space for the future. Hence, it is important to understand the architecture as a powerful tool in the determination of the place of the individuals or community transferring ideas and setting the criteria.

Let us remember that the architecture is a testimony on the creativity of humans in the field of construction and every moment that leads to its manifestation must be true. The truth is what was, what is valuable, what we found, which creates our memory, culture, identity and wealth. Without that there is no truth, otherwise there is no identity, no culture, no space, form, history, tradition, that tells the truth of human creative works. In specific complexity of its always peripheral location against major cultural and political centres, the cultural identity of Bosnia and Herzegovina was created out of its sources susceptible to the various influences as well as social awareness. The creation of such socially irresponsible architecture would contribute to necessity for redefinition of the architectural processes if we aim to build buildings, which respect the past and open new visions of the space for the future.

"... In contrast to the other arts, such as, painting, picture frame where exactly encloses the scope of work of art, architectural work was never completed as a whole ... in the context of the larger unit $i$ the importance of the artistic value of the individual works is finally formed. "21

Using the example of the Historical museum we refer to the memory and cultural identity of social and context aware architecture as a genius loci of the city of Sarajevo. Such created habitus is an extraordinary environment for evolving cultural identity through responsible architecture. Ars Aevi museum, with its concept and significance to the city and citizens of Sarajevo, by being materialised through architecture building, will manifest the Deleuzian notion of becoming-in-the-world. There are many issues that relate directly to the needs and ways of redefining cultural identity, as well as the role of architecture in this complex process. The case of Bosnia and Herzegowina and building the Ars Aevi museum with an international collective, will require an analytical approach to the creative renewal that paves the way to the Ulrich Beck's concept of "transcultural", open and diverse. This is how cultural identity intertwining should be approached in the time of globalization.

21. Aleš Vodopivec, Iz arhitekture [from architecture] (Ljubljana: HAC VIA d.o.o., 1991), 26. 


\section{Bibliography}

Assmann, Jan. "Collective Memory and Cultural IdentityFrankfurt/Main." In Kultur und Gedachtnis. Edited by Jan Assmann and Tonio Holscher. Suhrkamp, 1988.

Assmann, Jan. Cultural Memory Studies. An International and Interdisciplinary Handbook. Berlin, New York: 2008. 109-118.

Augé, Marc. Non-places. Introduction to an anthropology of super modernity. London /New York: Verso, 1995. 75-115.

Beck, Urlich. Šta je globalizacija? [What is globalization?] Zagreb: Vizura, 2001.

Dovey, Kim. Becoming Places Urbanism/Architecture/Identity/Power. New York: Routledge London, 2010.

Ešegović, fra Marko. Svjetlo riječi [Light of the word.] Sarajevo, 2011.

Hadžimuhamedović, Fehim. Katedrale novog duha; Društveni red arhitekture [Cathedrals of new spirit; social order of architecture.] VIZURA, 2007. 4-17.

Ibrišimbegović, Senka. Arhitektura muzeja savremene umjetnosti kao kapsula vremena [Architecture of museum of contemporary art as time capsule.] Sarajevo: PhD Dissertation, 2015.

Leach Neil. "Belonging: Towards a Theory of Identification with Place." Prospecta 33 (2002): 126-133.

Lefebvre, Henri. The Production of Space. Oxford Blackwell Publishing, 1991.

Liebeskind, Daniel. "Traces of the unborn." In Architecture and Revolution: Contemporary Perspectives on Central and Eastern Europe, 256. Edited by Neil Leach. London: Routledge, 2003.

Maroević, Ivo. ČOVJEK I PROSTOR Novija muzejska arhitektura u Hrvatskoj [Recent museum architecture in Croatia.]

Mrduljaš, M. and V. Kulić. "Unfinished modernisation." Cres/Fort Lauderale May (2012).

Navarro, Zander. In Search of a Cultural Interpretation of Power: The Contribution of Pierre Bourdieu. IDS Bulletin, 2006.

Norberg-Schulz, Christian. Egzistencija, prostor i arhitektura [Existence, Space \& Architecture.] Beograd: Građevinska knjiga, 1999.

Relph, Edward. Place and Placelessness. London Pion, 1976.

Tomlinson, John. Globalization and Culture. Nottingham: The University of Chicago Press, 1999.

Ugljen-Ademović, Nina, Elša Turkušić and Senka Ibrišimbegović. "The Process of redefining Cultural Identity in Societies in Transition- case study: Historical Museum in Bosnia and Herzegovina." Proceedings of $2^{\text {nd }}$ international conference, Architecture and Civil Engineering. (Singapore: ACE, 2014).

Vodopivec, Aleš. Iz arhitekture [from architecture.] Ljubljana: HAC VIA d.o.o., 1991. www.nasponline.org. 
